\title{
Competing Powers \\ Engineers, Energetic Productivism, and the End of Empires
}

Daniela Russ \& Thomas Turnbull

"Tons of data go with Wilson party," read the New York Times of December $4^{\text {th }}, 1918$. The newspaper article described how three truckloads of geographical and economic records had accompanied President Woodrow Wilson as he had left for the Paris Peace Conference (Smith 2003: 488). The US not only brought money, weapons and soldiers to Europe, but geographic expertise. In September 1917, Wilson had decided to gather a group of experts to quietly prepare the US's position in the post-war scramble for territories among rival and allied powers. Known as 'The Inquiry', the organization was akin to a foreign policy think tank, insofar as it brought together geographers, historians, and economists in the production of an impressive amount of data and reports surveying the post conflict landscape in a purportedly scientific manner (ibid: 119). World War I had swept away empires, and the maintenance of peace was believed to depend on the redrafting of territory on the basis of self-determined nation-states; in effect, the Inquiry's challenge was to assign every European coal mine and river valley to what was deemed its rightful place (ibid: 149).

The geopolitical worldview the US brought to the conference table emphasized a model of economic development freed from the need for territorial expansion. This North American principle had developed since the closing of the frontier and the inter-imperial wars of the late 19th century (see Nagel/Werron this volume). Territorial questions were still at the center of the peace talks, but, according to the Americans, they were the vehicle to achieve that peace, not its purpose. With the territorially defined nation-state came the idea of a world economy in which territorial size no longer determined economic significance (Smith 2003: 141-2). However, territorial quality still mat- 
tered: questions of resource supply, transport routes, and access to the sea were seen as crucial to the economic survival of nation states. In line with its earlier Open Doors Policy, with regard to trade with China, the US sought a post-war world with free, supposedly non-discriminatory access to goods and capital: a world in which, with America at the helm, territorial conflict would give way to 'peaceful' economic competition (Tooze 2015: 15-16).

In a time of rapid technological change, the economic diagnosis that lay behind the US position was shared by a wider cast of historical actors. Engineers and natural scientists who had risen to managerial or public positions began to articulate a new view of economic progress based on the efficiency of resource use rather than the assumption that monetary economy was alone sufficient to guarantee economic development (Hays 1999; Tyrell 2015). The pursuit of resource efficiency implied a materialist, if relativistic, view of the economy: in contrast to neoclassical economists, these critics defended the idea that wealth must be measured in material terms and pointed out the arbitrariness of the allocation of price by markets alone and the inefficiencies of price-governed forms of economic policy. Moreover, against the scarcitymongering of some earlier classical economists, they emphasized the emancipatory role of technological progress. The fact that more was increasingly being produced with less introduced a certain relativity to the determination of absolute material limits (Turnbull 2020), while new means of production, particularly those powered by electricity, added plausibility to this new efficiency-centered materialist economics.

Referring to a series of scientific and social initiatives in the 19th century, historian Anson Rabinbach has used the term 'productivism' to describe the widely held belief that 'energy' was the ultimate source of all productive power, human, animal, or mechanical (Rabinbach 1990: 61; Underwood 1995). Drawing on thermodynamics, a vision of an economy governed by contrasting principles of work and waste had been a widely shared belief amongst physicists, engineers, physiologists, and political economists in the mid-19th century (cf. Wise and Smith 1989a; 1989b; 1990). The rise of price-based, neoclassical economics at the end of the 19th century superseded these views, concealing almost all traces of natural-economic thinking in mainstream economics (Mirowski 1989; Schabas 2005). A later productivism, as espoused by German national socialists and Italian fascists, no longer reflected a natural philosophical idea of nature and society united in production, so much as a technocratic idea of total societal management (Maier 1988: 77; Rabinbach 2018). By the 1950s, both forms of productivism were increasingly sub- 
sumed under the global rivalry between the capitalist principles of efficient resource allocation and the socialist principle of material balancing (Arvay 1994; Mirowski 2002).

We term this short-lived interest in an energy-based form of materialist economics during the interwar period as 'energetic productivism.' Rather than the gradual decline of materialist economics, we propose to think of energetic productivism as a brief period of enthusiasm for a distinct form of materialist economics. It was not materialism in retreat, but a reformulated reiteration of materialist thinking: a response to the changing technological, economic, and political conditions of the period. Energetic productivism was based on the idea that the amount of energy a state could harness and control was a central indicator of its economic and political power. Energy was understood as a resource but one that was relative to the efficiency of a state's working population, its productive technologies, and the efficacy with which the state was able to configure these productive capacities. Energy availability, in effect, was a function of a state's ability to make advantageous use of material resources. This body of ideas recognized that it was longer a state's absolute amount of territory, its population, or resources that determined its power, so much as the energy that could be productively harnessed from these potentialities.

Energetic productivism, we further argue, implied a form of indirect competition for a reliable, broad, and efficient use of energy. While this form of competition clearly did not rule out national conflicts over resources and territories, it created a new medium via which supremacy could be asserted: How long would a country's coal resources last? How much waterpower could be harnessed? How many homes and industries could be electrified? How much mechanical power could an average worker exert? Countries observed each other closely through official statistics, meticulously comparing one another's' energetic capacities, and striving for the recognition of comparative advantages from an increasingly international public sphere. While preferable to direct conflict, we argue that this form of competition was only 'formally peaceful'. As Max Weber stated "only complete political confusion and naive optimism" could mistake pre-war expansion of imperial trade for peaceful economic competition (Weber 1894, quoted in Mommsen 1990: 77). Such a view also applied to competition over energetic productivity in the interwar years.

Energetic productivism changed the terms of geopolitical competition and the nature of imperialism. In the following two parts, we first outline the roots of energetic productivism in the 19th century and show how it re- 
lated to imperial competition around the turn of the century. We then turn to two forms of energetic productivism that emerged out of two distinct nation states, Great Britain and the Soviet Union. On the basis of these examples, we argue 'power competition' was wedded to two wider political conflicts. The first was between Great Britain and 'rising' rival powers whose ascendence was beginning to end its industrial and political hegemony. The second power competition occurred between the Soviet Union and the capitalist countries whom this experimental new polity sought to supersede. The chapter concludes by contrasting these two iterations of energetic productivism with a more well-known formulation of energetic statehood proposed in the US in the 1930 s.

\section{Energetic Productivism}

In the interwar years, energetic productivism drew its persuasive power from economic uncertainties, technological change, and visionary plans for the future. Its roots, however, lay in the age of the steam engine and the science of thermodynamics. Rabinbach has traced the metaphorical idea of humans as motors and the idea that society should be governed according to thermodynamic imperatives back to the early 19th century, while others have associated such a view with advances in engineering, political economy and natural philosophy (Rabinbach 1992; Breger 1982). In this 19th century iteration, productivists espoused the idea that humans, animals and nature shared an ability to do work. Productivism linked human life processes to those of other species and to natural processes, such as photosynthesis and the combustion and the generation of heat. Because this productivism rested upon physical principles, its advocates believed it articulated universal principles for the improvement of human existence.

This physicalism was particularly apparent among those who became known as energeticists, a loose group of natural scientists who on the basis of the seemingly universal applicability of the laws of energy ventured into the social sciences at the end of the 19th century. For mathematician Georg Helm, and chemists Ernest Solvay and Wilhelm Ostwald, energy could no longer be solely a matter for engineers and natural philosophers but the basis of a program of societal reform (Müller 2020: 37). Solvay and Ostwald drew a strong moral lesson, an 'energetic imperative' which saw civilizational advancement as something dependent on more efficient use of available 
energy resources. As Solvay pointed out, this obligation was grounded in human physiology: "The productivist movement has its source in social energetics; it expresses itself physiologically and socially in the law of struggle for the best existence which, itself, is only an expression of the superior physico-chemical law of maximum work" (Solvay 1900: 150, our translation). Under this law, colonial expansion was also cast as an energo-moralistic obligation. The productivist law that "generates the well-being of humanity and will consequently constitute the universal law [...]. It [...] legitimizes from a humanitarian point of view the forced imposition of the system of full productivism or the forced political or territorial occupation of the least developed countries by the most advanced productivist countries." (Solvay 1900: 73, our translation; cf. Ostwald 1912; Rabinbach 2018). For Ostwald's fellow energeticist and Leipzig university colleague, the geographer Friedrich Ratzel, by contrast, colonial expansion was a means for the maximization of resources which fecund but supposedly lesser nations were unable to exploit to their fullest potential. This was a rationale underlying his infamous concept of Lebensraum: the idea that state seizure of territory was defensible as a requirement of societal evolution (Livingstone 2008).

Proponents of energetic productivism articulated a belief that mastery over the physics of energy conversion determined economic productivity and the creation of value. But as economies had become more dependent on technology, this energo-physicalism could no longer be quantified solely in terms of population, acres of land or resources. It had become instead a function of the effective use of technology, labor, and nature: in sum, the determinants of a nation's capacity to productively expend available energy. Rabinbach termed such productivism "transcendental materialism" (1993: 4) to characterize how the mobilization of matter via energy transcended and extended conventional materialist economics: as alongside a focus on matter and bodies it stressed that energy offered a unified form of explanation. Manifest in acts of measurement that attested to the efficiency of industrial processes, such potentialities were seen as the energo-material basis of economic life and pitted against economic theories that focused on immaterial and subjective determinations of value (cf. neoclassical orthodoxy). In the productivist view, the financial economy could obscure the true determinant of economic growth and detract attention from the pursuit of technological efficiency. For example, in US institutional economist Thorstein Veblen's radical polemics, the most productive economy would be that which freed itself from the restriction to pursue profit above all else (Veblen 1975). 
Like no other technology, electrification exemplified the changes afoot in the pursuit of economic progress. Commercial electricity had begun as a means of lighting and a communication technology. By World War I, it had become the connective tissue of the machine industry that supplied electric power and machinery for all kinds of purposes, spawning new industries such as electrochemistry (Hughes 1993: 285-323, Friedrich/James 2017). By conveying electricity generated by a smaller number of large power plants of greater efficiency than discrete steam engines, and dispersing this across an interconnected grid, significant efficiencies were achieved, and dramatic claims were made about electricity's coal saving capacities (Zimmermann 1933: 569). Moreover, for countries with limited access to coal, or those looking to supplement its power, mechanized industries and infrastructures could be driven by electricity derived from falling water. Electric power could also be used more efficiently than steam in productive processes, it could be split and employed where needed and could replace or amplify human labor. Electrification came to be understood as a lever which, properly employed, could augment economic productivity (Hausman et al. 2008, 27).

Against the backdrop of a confusing and unexplained economic depression, marked by falling prices and competing views regarding business cycle amplitudes, energetic productivism offered a theory of economic development which could draw on the authority of the natural sciences and engineering. This authority was greater than ever after World War I: a conflict that had been fought to a large extent with cutting-edge scientific advancements, which had brought more scientists and engineers into public office, and in which engineering principles had begun to be applied to economic planning (Thomas 2015: 13-21; Meer 2012). Energetic productivist thinking was seemingly most common in the fields of economic geography, industrial chemistry, and electrical engineering, areas in which the efficiency gains and spatial and economic changes heralded by new energy technologies were readily apparent.

Crucial to this world view was a distinct theory of progress, in which civilizational advancement was primarily determined by the predominant source of energy that was used. The rise of electricity coincided with a number of theories of 'energy development', the idea that society progressed through increases in the quantity and quality of energy that was available for use. These theories had found an early expression in the sociology of Herbert Spencer, and subsequent organistic theories of state, which posited that society was an aggregate of evolving energy-dependent organisms (McKinnon 2010). Theo- 
ries of energy-based societal development found full expression in the work of North American historian-philosopher Lewis Mumford, who saw electricity as an energy form that would allow society to shift from a "paleotechnic" coal-based existence toward a cleaner and more prosperous "neotechnic age" (Mumford 1934). It is perhaps unsurprising that the first reinterpretation of the industrial revolution as a coal-driven historical event emerged around this time (Nef 1932). But however diverse the intellectual threads of energy productivism, they were united by a shared understanding of history as something driven by techno-economic rationales. In attempting to outdo each other in terms of energetic capacity, countries competed via a new form of developmental supremacy.

\section{Energetic Imperialism}

The last quarter of the 19th century marked the beginning of a period of intensified rivalry between the great powers. Imperial Germany and the US were rapidly industrializing, and their industrial products had begun to compete with those of Britain (Friedberg 1988: 35). Former outliers such as Tsarist Russia and the Ottoman Empire had built railroads, welcomed some foreign investment, and slowly begun to modernize their economies. When the great powers sought to resolve their territorial rivalries by dividing the African continent among themselves at the 1884-5 Berlin conference, the last 'frontier' of land available to Imperial states was reached. The globe's North and South poles would soon be reached, and just one seventh of the Earth would remain unmapped (Smith 2003: 11). Given evidence of territorial limits to growth, the scramble for the last 'unclaimed' territories had also been fuelled by fears prompted by falling prices and investments, dynamics later classified as perhaps the first 'Great Depression', lasting between 1873 and 1896 (Saul 1985; Hobsbawm 1989). This insecurity raised doubts about the economic advantages of free trade and imperialism and encouraged new forms of economic organization. Many countries introduced tariffs to protect their domestic and colonial industrial interests from international economic competition (Hobsbawm 1989: 39-42).

What made this 'depression' so hard to grasp is that while prices and investment fell, wages and production increased, and profits soared. This discrepancy sparked discussions over the contested relation between productivity and profitability within businesses but also in regard to the wider logics of 
imperial economies. Businesses responded by attempting to avoid increased competition via cooperation, vertical integration, and scientific management (Chandler 2002). The large shareholder corporation with its meticulous accounting system reached maturity in the late 19th century, soon followed by Taylorist principles of scientific management in the early twentieth century, which espoused the idea that laborers could be disciplined to make more efficient use of time and motion in productive processes (Maier 1970). A tendency toward the formation of monopolies or monopolistic forms of cooperation was particularly great in both new and old networked and energy industries, such as coal, railroads, oil and electric power (Hobsbawm 1989: 44). The large trusts and monopolies of the rising industrial powers-Germany'scoal syndicates and the oil and power companies of the US-exemplified this tendency. By the outbreak of World War I, German and American electric power companies dominated electric development world-wide (Hausman et al. 2008: 75105).

To some, such end of the century imperial competitiveness and skirmishes over productivity seemed directed more toward the attainment of private profits than national advancement. In Imperialism: A Study (1902) British economist John Atkinson Hobson proposed a relationship between domestic underconsumption, foreign investment, and imperial expansion. In his view, there were powerful domestic interests benefitting from imperialism: namely manufacturers and, particularly, investors (Cain 2002: 103-114). In a peculiarly energetic metaphor, Hobson noted that "finance is rather the governor of the imperial engine, directing the energy and determining its work; it does not constitute the fuel of the engine, nor does it directly generate the power." (Hobson 1902: 59) In an expression reminiscent of the later technocratic criticism of "financial managers" (Veblen 1921: 29), Hobson suggested finance was important only in so far as it governed the rate at which energy entered the economy.

The World War made both the dependency on financial markets plainly visible and sparked a hope among some that a new, energo-materially oriented reorganization of economic life might be achieved. The allies had borrowed heavily from Wall Street, creating a strong link between entrenched financial interests and the European conflict. While this was not the trigger for the US joining the war, it established a dependency that could not be neglected: not least because, during the war, the US turned from the world's largest debtor to the largest creditor nation (Wilkins 2009; Tooze 2015). It replaced an international financial system based on the gold standard and cen- 
tered around London with a new system that gravitated towards Wall Street. However, domestic war economies, particularly the German War Resource Department, were able to prove that another relation between the state and capital was possible: the centralized administration of production, allocation, and consumption that was based not on world market prices but on the material prosperity of the 'nation' or 'community' (Maier 1970; Hardach 1981: 58-62; Michalka 1997).

Colonialism was officially outlawed after World War I but continued under the mandate system of the League of Nations. In fact, the modern oligopolistic oil industry, in which a handful of multinational corporations divided up global oil resources, emerged at that time. The mandate system prohibited annexation but allowed states to administer territories to "promote the wellbeing and development of [its] people" (Snow 1919: 68). Under this system, France and Great Britain split the former Ottoman territories in the Middle East and began to develop oil industries and pipelines in their mandate territories (Sampson 1975; Garavini 2019: 11-52). At the same time, the US oil companies founded the Arabian-American Oil Company (Aramco) outside of the mandate system, but under equally favorable business conditions. These 'post-imperial' undertakings, in which territory was not seized, but access to resources was secured through long-term treaties within mandates or with formally independent states, were often more profitable than direct imperialism (Strachey 1959: 179). This modified colonialism, in which resource access trumped the burdens of territorial ownership, was referred to by Isiah Bowman, geographer advisor to President Franklin Roosevelt, and leading Inquiry member, as 'American Lebensraum', a term not solely applicable to the US but which acknowledged its oversight of this system of access-led resource appropriation (Smith 2003: 27-28).

The new order proved precarious. The national borders carved out at the Paris Peace Conference remained contested and global economic shock waves continued to hit even well-organized Volkswirtschaften (national economies). In fact, the suspicion that something was wrong with the international economic order became only stronger after World War I and the depression of the 1930s. The invention of macroeconomics and new economic theories, such as Keynesianism, neoliberalism, and business cycle research, were attempts to make sense of the changing relation between national and world economies (Tooze 2001; Slobodian 2018). While Keynesianism and neoliberalism focused on markets and the monetary economy, business cycle research picked up on the material and technological changes too. Soviet economist Nikolai Kon- 
dratieff built an economic theory on the history of industrial revolutions, which he understood as initiating 'long waves' of economic growth. Joseph Schumpeter picked up Kondratieff's ideas in his work on business cycles, in which he associated each upswing with a new set of innovations and each downturn with the exhaustion of their profit potential (Hobsbawm 1989: 47). In this view, the upswing around the turn of the century was linked to marked innovations in the electrical, petroleum and chemical industries. One British economist even saw electrification and the related spread of automation as signs of a "second industrial revolution", one which would prove more consequential than the first (Jevons 1931).

\section{Edwardian Technocracy}

Taking into perspective later eras of Depression, such as that of the 1930s, simplistic descriptions of the period 1873 to 1896 as a 'Great Depression' have met criticism, instead it has been suggested it was more a specific problem for the Victorian economy of Britain. Prices had indeed fallen, and this was registered in falling profits for those who owned productive means. Such industrialists, often with access to the press, were prone to raising the specter of depression in pursuit of sympathetic policies. Whether or not it was truly a depression, as it is understood in contemporary economics, some described it as such. This would, in contemporary parlance, involve a sustained fall in GDP which did not occur (Friedberg 1988: 24). But relative to the 'boom' of industrialism, which was most apparent in the early 1870s, even minor contractions in growth appeared significant. This was also a question of perspective. As Britain had industrialized first, productivity rate increases tailed-off there first. Decline and supremacy were relative phenomena: as other countries industrialized, learning from the prime mover's mistakes as well as its successes, their rates of productivity growth began to exceed those of Britain (Saul 1985: 23; Friedberg 1988: 24-26).

Little known today, a distinct energetic productivist movement emerged in Edwardian Britain in response to this perceived economic slump and a more wide-ranging belief in national decline. Faced with defeat in the Boer war, a conflict that had begun in 1899 and which had seen British soldiers disastrously deployed against the Transvaal and the Orange Free State, the collective belief in the country's natural supremacy had been shaken. In the words of foreign secretary Joseph Chamberlain, the nation was a "weary Ti- 
tan" undergoing relative decline in contrast to rival powers, particularly Bismarck's Germany (Friedberg 1988: 116). In response, calls for greater 'efficiency' in all aspects of statecraft came from across the political spectrum, providing, in historian Gerald Searle's view, "a cohering ideology" (Searle 1971: xxvi): a shared belief that national renewal could be achieved via internal improvements to the components of the British empire rather than, as in past decades, territorial expansion and the pursuit of untrammeled trade. The perceived economic depression between 1873-1896 had further undermined the tenets of British liberalism, whilst the interventionist policies of Germany, from conscription to state-sponsored science, suggested that the rationalization of state functions rather than imperial expansion would be the new determinant of power.

Seeking to address this challenge, in 1902 a dining club called the 'CoEfficients' convened in London. The event provided a forum for the leading figures in the British efficiency movement. Historian Robert Scally called it a "peculiar experiment in English politics", partly given its informal nature; "interesting little dinners" were overseen by Fabian socialists Beatrice and Sidney Webb, and attended by the science-fiction author H.G. Wells, the Hegelian philosopher and statesman Richard Burdon Haldane, and the geographer Halford Mackinder, amongst others (Scally 2015: 81-82). An indication of its influence is suggested by the fact that one member, Edward Grey, Foreign Secretary between 1905-1916, became a key figure in British foreign policy before and during WWI, and afterwards became president of the League of Nations. Historian Andreas Rose notes the club "provided the future foreign minister with not only a forum in which he could develop his thoughts but also a free lesson on the domestic problems that might accompany his proposed course of action" (Rose 2017: 87). Though it split in 1909, long before the war, the club provided a venue for discussing emerging concerns over Britain's relative decline, from the threat presented by an ascendant Germany to a potential alliance with Russia (Friedberg 1988: 86-87).

Diverse in political opinions, the group broadly coalesced under the twin banners of Imperialism and what journalist and Co-Efficient club member Leo Amery called its pro-interventionist "semi-socialism" (Scally 2015: 78). As Sidney Webb stated their aim had been high minded conversation that might lead to the development of a political program to address what was seen as "the pompous inefficiency of every branch of our public administration" (Searle 2002: 196). Through the advocacy of prominent Co-Efficients, moves toward the technical rationalization of state administration began to find a 
foothold in public life, particularly after WWI. Given its interstitial role, at least one historian characterized the group as an "Edwardian 'think tank" (Polelle 1999: 71). Amid a more widespread energy productivist movement, the Co-Efficients provided a distinctly British iteration of such thinking.

The formation of the Co-Efficients had been partly prompted by a growing sense that the competitive dynamics of free trade had failed, for Britain at least. Supporters of the Tariff Reform movement had argued in response to Britain's perceived economic slump that higher taxes should be imposed on domestic and foreign trade to increase state revenue and better provide for the security and welfare of the recently enlarged electorate (Thompson 1997). The 1867 and 1884 Reform Acts had created an upswell of political demands from the working classes. Though diverse in opinions, a significant number of Co-Efficients saw increased tariffs as a means of increasing the capacity of the state to invest in interventionist efficiency-oriented policies: from technical education to scientific research to improve worker efficiency, for the benefit of industry and the Empire in general. The question was whether free trade could be balanced with this more technocratic and welfare-oriented vision of the state. Not least, geographer Halford Mackinder saw the origin of British decline in the nation having measured its prosperity according to the value of foreign trade. In his mind, the pursuit of "Money-power" served only as a measure of the rate at which the British Empire was divesting itself of its resources (Mackinder 1906). In its place, he believed the nation should strive toward increased "man-power", a measure of a population's potential "laboring and fighting power" (Mackinder 1905).

Mackinder's formulation of energetic productivism was distinguished by its focus on human physiology. At a lecture to the Compatriots Club, a more overtly Imperialist spin-off group from the Co-Efficients, he asked his audience "to turn for a while from thought of values, and even of wealth itself, to the output of human energy for which wealth affords but part of the fuel" (Kearns 2009: 55; Mackinder 1906: 21). He believed wealth measured in pecuniary terms was no indication of physiological power, nor did it confer levels of resource wealth, as via competition, war, and increased efficiency, the availability of resources could be dramatically increased. For Mackinder, the ultimate determinant of national power was the size and efficacy of its population rather than currency or resources. His point was that via competition, efficiency, or war one could dramatically increase resource availability, so the ultimate determinant of productive and martial power was the size and efficiency of a potentially working or fighting population. Mackinder was less 
interested in the "sources of human energy" (1906: 143), coal and oil or agricultural produce, than in the energetic capacities of human bodies such sources could support and improve.

How could such measurements of manpower be accounted for? Given his social Darwinist beliefs, he argued that it was not possible to simply count the number of people in a given state, as that would assume "all men are equally efficient" (ibid: 136). Comparing Britain to other nations revealed that a focus on money-power at the expense of other values had left the nation's population growing more slowly than almost all other European states and paling in comparison to Russia and America's abundant citizenry. Moreover, the conscription of soldiers during the Boer war had revealed a section of working people who had been rendered anemic, malnourished, weak, and poorly educated (Searle 1971: 65). Mackinder believed that if the state were to invest in this underclass's educational improvement, administer to their health, and improve the human stock through eugenic interventions, individual units of manpower could be increased, and Britain could re-assert itself against the stronger bodies of Wilhelmine Germany (Searle 1976). In this distinctly biopolitical formulation, the health and efficiency of working and fighting bodies became the focus of this particular form of late Imperial energetic productivism.

The idea that efficiency increases provided a means of restoring national competitiveness was central to Mackinder's geopolitical vision. From a geographical perspective, he believed the year 1900 had marked the beginning of a 'post-Columbian epoch', the end of an age of sea-power in which the earth had been circumnavigated and almost wholly mapped. This known planet was now "a closed political system" in which political attention had to shift from conflictual "territorial expansion to the struggle for relative efficiency" (Mackinder 1904: 422). The pursuit of efficiency, a goal that was relative rather than absolute, offered a new competitive domain within which the global balance of powers could be fought over. The goal was by no means equality but continual struggle to maintain a relative position against increasingly powerful rivals. Seen as a component of a more widespread energy productivist movement, Mackinder's aim was to improve the quantity and quality of physical manpower as means to reinvigorate a declining Empire.

What effect did such ideas have in practice, and were such ideas confined to imperialistic geographers? World War I was of great consequence in shifting the onus of productivity from human labor to electrical power. Another former Co-Efficient, Haldane, had been Secretary of State for War, and after- 
ward led a Parliamentary committee to address the conservation of coal, as part of national reconstruction efforts. In this role, with the help of the acclaimed electrical engineer Charles Merz, Haldane would help promote electrification as a means of increasing both the power and efficiency of Britain. The Coal Committee's central argument was that "the question of the conservation of coal is the question of economy in the use of coal through supplying electricity" (Haldane and Merz 1918). Their final report proposed that the existing electricity industry, composed of 600 privately owned small-scale plants, should be replaced with a rationalized system that divided Britain into 16 regions, each with a "super" electrical power plant. Connections would create a vast "interconnected power distribution system" spanning the entire nation; this "gridiron" could act as a means of transporting power equivalent to that of a thousand of tons of coal at any interconnected point across the British Isles (Cochrane 1985).

In an extension of Mackinder's emphasis on efficiency led individual improvement, Haldane's report on coal conservation had called for national electrification on the basis that it would increase the productivity of British manpower. In a formulation we might expect more to have come from Vladimir Lenin, the Committee's final report stated: "It is only by largely increasing the amount of power used in industry (by two or more times) that the average output per head (and as a consequence the wages of the individual) can be increased" (Haldane and Merz 1918: 8). Haldane's investigation into the conservation of coal had concluded that the key to national wealth lay in "the greatest possible use of power", not in a figurative sense, nor in the purely physiological sense of Mackinder's pre-war formulations, but by efficiently transforming coal into a stream of electrons that could be used to augment the power of human labor. As it was, nationalized electricity would not emerge until 1948, but the report led to the establishment of a Central Electricity Board in 1925, which began a program of connecting existing small networks into a larger grid (Hannah 1979). Such interventionist and centralized planning proposals would have seemed almost unthinkable to a previous generation of diehard Victorian liberals.

\section{Socialist Energetics}

Energetic productivism in Russia has to be seen in the context of catching up with the Western industrial powers. In terms of the extent of industrializa- 
tion and the development of institutions, pre-war Imperial Russia was closer to Asia, the Middle Eastern or Latin America (Allen 2003: 3f, 16). The Tsarist state had already embarked on a slow course of modernization in the 19th century. It harbored imperial ambitions in Siberia and, like Britain, suffered a painful defeat from a 'rising power' in the Russo-Japanese War in 1904-5. By then, it had established six non-military technical schools, opened the oil industry in Baku to foreign capital, and had begun constructing the TransSiberian Railroad (Balzer 1980: 18; Barnett 2004: 29; Moser 2018). Supported by the military and small technical societies, electrification slowly spread between 1880-1914, particularly around industrial centers (Cummins 1988: 41, Coopersmith 1992: 45-59). These changes galvanized a small cadre of modernizers and technical intelligentsia.

World War I accelerated the dissolution of the Tsarist regime and provided an important spark for the revolutions of 1917. The Bolsheviks inherited an economy that was very unevenly industrialized, and many technicians and engineers were ready to put their expertise at the service of the new state (Bailes 1978: 19-43). The war experience also gave a new urgency to the idea of the rational management of production based on the newest technologies. Lenin had first been skeptical of scientific management, but after the war approved of it: "The war taught us much [...]," he noted in 1918,

"but especially the fact that those who have the best technology, organization, discipline and the best machines emerge on top; it is this the war has taught us, and it is a good thing it has taught us. It is essential to learn that without machines, without discipline, it is impossible to live in modern society. It is necessary to master the highest technology or be crushed" (Bailes 1978: 49; Bailes 1977: 376).

While not all Bolsheviks were prone to such technocratic faith, Lenin and a number of Bolshevik engineers believed the latest technologies were necessary to the survival of the young socialist state. Until his death in 1923, Lenin would continue to push for the inclusion of technical experts in the planning institutions of the Soviet Union-a policy of which Stalin was very critical.

Lenin's illness and death sparked not only a power struggle within the communist party, but also conflicts over the course of industrialization. These include the well-known controversies around the 'retreat' to state capitalism (the New Economic Policy) and the pace of industrial development as indicated in the goals stated in the Five-Year-Plans (Erlich 1967; Carr 1979; Siegelbaum 1992: 82). Much lesser known is the conflict between Viacheslav Molo- 
tov, Stalin's trusted industrial administrator, and Gleb M. Krzhizhanovskii, an old friend of Lenin, who headed both the state electrification commission (GOELRO) and the state planning commission (Gosplan) in the 1920 s. Planning methods had always been contentious (Haumann 1974), but in the late 1920s, the institution of long-term planning was challenged as such, and Gosplan became a site of Stalin's struggle against the older Bolshevik intelligentsia.

Drawing on the experience with the first large-scale economic plan, GOELRO, Krzhizhanovskii and other engineers had developed a theory of energetic development-energetika-which emphasized electrification as the 'technical-economic basis' of socialism. Attacking the authority of the GOELRO and Gosplan engineers and planners, Molotov shifted the focus on the importance of technology in a general and favored rapid industrialization on the basis of mechanical engineering, not electrification (Flakserman 1964: 145-150; Davies 1996: 135-137). While this had only little influence on the level of electrification, it cut short the administrative careers of the energetiki and neutralized their critique of Stalin's energy policies. Having lost their positions at the center of economic planning, most of them found a new home in the Institute of Energetics of the 'bolshevized' Academy of Science.

Energetika is most closely associated with the life and work of Gleb M. Krzhizhanovskii, an early Bolshevik and engineer who had worked for the railroads and developed a peat-fired power station under the Tsarist regime. As a technically versed comrade in arms, he rose to public office after the Bolshevik revolution and headed the central administration of the power industry (Glavelektro). The idea for an all-Russian electrification plan can be traced back to conversations between him and Lenin (Cummins 1988: 6668). Krzhizhanovskii was widely-read and very familiar with the Socialist discourse of the time, but he understood himself rather as an engineer and poet than as a theorist of the revolution. Lenin had to push him to reformulate the electrification plan in a less technical way and to strengthen its character as "a political or state plan" (Krzhizhanovskii 1936: 97). In his double role as head of GOELRO and head of Gosplan, Krzhizhanovskii tried to more explicitly link electrification to the problems of constructing a Socialist economy (Russ forthcoming).

This broader understanding is already apparent in some of Krzhizhanovskii's early remarks. By 1923, he had developed an idea of energetics that was anchored in, but no longer limited to, electrification. In a discussion on wages in Gosplan, a delegate asked why an increase in productivity preceded an 
increase in wages and how that time lag could be explained. This knowledge, he added, would surely be of the greatest importance for managing the selfconsciousness (in that case, the acceptance of low wages) of the masses. Krzhizhanovskii replied that "the formula that gives the true perspective of economic development [razvertyvanie] and the right approach to its higher forms-is energetic." This formula, he pointed out, was not that of Taylorism or scientific management, nor was it the mechanization of labor as pursued in GOELRO. The formula came close to GOELRO's method: a method of material efficiency. He envisioned energetics as a "skeleton," which, once its construction was mastered, would in a "kind of automatism" realize the maximum production of labor with the smallest expenditure of energy (State Planning Commission 1923: 46f).

What Krzhizhanovskii and the other energetiki had in mind can be seen from their work on the reconstruction of economic regions (raionirovanie). In 1920, the All-Russian central executive committee (VZIK) formed an administrative committee to prepare a method of raioniravonie and make a proposal for the precise course of regional borders. As part of this work, a subcommission within Gosplan was formed, which was headed by Ivan G. Aleksandrov, a GOELRO engineer and economist, and Krzhizhanovskii. Drawing on their work on regional power stations as part of GOELRO, they developed an understanding of economic regions as "combined production complexes" formed according to "energetic principles", self-sufficient, but open, economies (Krzhizhanovskii 1957; Karelin 2010: 15). Water power and longdistance transmission would allow the location of new branches of industries in underdeveloped areas. This concept of regionalism was explicitly contrasted with the uneven development of industry in capitalist countries: Socialist regions would be as autarkic as possible in terms of energy and would otherwise specialize in different industries according to locally available resources and climatic conditions.

Krzhizhanovskii understood his energetic plans as a distinctly Socialist realization of a productive potential that had developed under capitalism. He surmised that behind the historical form the power industry had taken in capitalist countries lurked the truth of energetic principles. This common point of reference both justified international comparisons and was actualized by them. In his first speech 'Electrification and the Planning Economy' after Lenin's death in 1924, Krzhizhanovskii emphasized electrification as a general technological development, referring to the commissions in Britain, France, and Bulgaria (1924:3). Gosplan dedicated fifty pages of its bulletin to a 
discussion of the first World Power Conference (WPC)—an international conference on the power economy-to assess GOELRO against other countries' planned electrification. The report concluded that GOELRO was in line with the two basic principles of modern electrical development projects: concentration and interconnection. Capitalist countries, gloated the reporter, became aware that competition in electrical systems was detrimental because of the need for multiple investments in a parallel infrastructure (Kukel' 1925: 131-133). To the Soviet energetiki, the planned forms of economic organization in capitalist countries - trusts, syndicates, and institutions of the war economy-were evidence of a general economic development and as such deserved attention. They were truth in a wrong form: rational organization separated from the struggle to realize a Socialist order.

In Newcastle-upon-Tyne, the heart of the British coal industry, the engineer Charles Merz, already discussed in the previous section, had demonstrated as early as 1904 that the bigger the plant, and the greater the mix of load profiles, the greater the operating efficiency and profitability that could be achieved. ${ }^{1}$ If not Merz's iteration in particular, this general model of electrical development, emphasizing economies of scale and the mix of different load profiles to increase profitability, had become widespread in the 1920 . In fact, the GOELRO system of large regional stations followed this model, brushing aside more radical approaches (Coopersmith 1992: 151). The energetiki interpreted this as a general turn to centralization as capitalist countries unconsciously following a form of technological development which would eventually usher them into socialism. The Soviet engineer Modest Rubinstein would later argue that socialism was a necessary precondition for the 'full development' of electrification (Rubinstein 1971: 189). British Conservatives thought much the same about its centralizing tendencies and argued Haldane's plans for centralized electrification was "jumping the first fence of socialism" (Hannah 1979: 330). In the words of Gosplan's American correspondent, electrification would be capitalism's last technological achievement.

When Stalin announced the building of socialism in one country in 1925, these comparisons took on a less emancipatory and more competitive form. Electrification would not only soothe internal disagreements but also mediate external conflict: Electrification was a weapon in an economic war. "The general situation is such," reflected Krzhizhanovskii (1925a: 12) under the impres- 
sion of the first WPC and reflecting a sentiment similar to that of Mackinder's geography of efficiency, "that in the near future the center of the gravity of struggle shifts from military to economic conflicts." Not for a moment did he fall for the supposed peaceableness of the 'technocratic internationalism' championed by the British host, who pictured all nations advancing together by making use of the "marvelous resources of nature" (WPC 1925: viii). For Krzhizhanovskii, the WPC was a tool of the electrotechnical industry, which, accelerated by wartime industry, was desperately searching for new markets. He was convinced to live in a moment in which international conflict "expresses itself in the struggle for energetic resources." What he meant was not so much territorial struggle, but a race to develop one's territory: "If we look at what is done in America (sic), how they build their economic proposition, then you can see that this powerful state pervades itself with 'energetic rails' and grids, which become the backbone of its economy." (1925b: 11) The Soviet state had to do the same, but better, to win the economic war for the future (Coopersmith 1992: 251).

Krzhizhanovskii thought that it would be possible for a socialist country to catch up and even surpass capitalist countries. Only socialist countries could combine central planning with national ownership of power utilities and industries, so that the interests of producers and consumers were aligned, and electrification would operate as a rationalizing and socializing force. Even if the energy economy of capitalist countries-calculated in the physiologically centered amount of power produced per person-was still many times more powerful, their forces acted chaotically against each other, in a "complex polygon" (Krzhizhanovskii 1928: 35). When the metabolism of nature and society was rationally regulated, Krzhizhanovskii argued, the 'forces of nature' and human labor would come to work in parallel, as a single, rectified force. Through rational planning of the energy-equipment of labor, the Soviet Union would appropriate the energetic law of economic development and accomplish it. The struggle against and emancipation from the elements of nature was universal, and the Soviet Union should be judged in terms of the amount of natural power it was able to exploit (Krzhizhanovskii 1928: 18).

Krzhizhanovskii wrote his strongest papers on energetika in preparation of the first pyatiletka between 1925-1928. By that time, he felt ready to make "an energetic approach to economic problems" the basis of the first prospective plan (1925b: 10), and energy indeed had a prominent place in the plan (State Planning Commission 1930: 24-26). Scholars in the Communist Academy of Science picked up energetic ideas and began empirical studies, which, in turn, 
helped to make Krzhizhanovskii's thinking more specific. However, this was also the time when his influence in Gosplan was already waning. Stalin's path to securing state power made use of industrial policies in an instrumental way and cut short many alternative projects and approaches to planning (Shearer 1996: 12-13). He had long been sceptical of the technocratic engineers of Gosplan and was eager to demote them to less influential positions. The model of industrial development shifted from a focus on electrification to machinebuilding and Krzhizhanovskii's electrification plan for the Second Five-YearPlan was quietly ignored by Stalin and Molotov (Bailes 1978: 185). In the perspective of this view on economic development, the output of electricity was now no more important than the output of tractors to catch up with capitalist countries. While material accounting continued to play a role in Soviet planning, there was no equally bold vision of a moneyless economy after 'energetika': the energetiki were, arguably, the last Soviet planners who believed they were building an economy in kind (Davies 1996: 463).

\section{Epilogue}

In 1933, the North American engineer Howard Scott argued in the nation's press that the mass unemployment and economic stagnation of that decade's economic depression had resulted from a collective failure to understand that "physical wealth is not measured in terms of labor, goods, or money, but in terms of energy" (Scott 1933). Measured in ergs, joules, and calories, energy was a unit in accordance with universal laws, a more precise indicator of wealth than dollars, whose value was relative to that of other currencies and subject to inflation. With no metrological consistency and no direct relation to the material world, dollars were "a purely arbitrary unit" (ibid). Seemingly unmoored from physical reality, Scott believed pecuniary economics had caused the dramatic imbalances to the US economy that were currently at work. Having risen unaccountably, prices seemed no longer to correlate with utility. Moreover, their value merely reflected the tenets of wasteful competitiondriven transactions, obsolescence, and debt rather transactions that meet human needs. Simultaneously, technological advancement was undermining the human components of industrialism; productivity increases were no longer dependent on increased human labor, and this had created technological unemployment. 
Scott's solution to economic depression had lain in physics, as he stated "the law of Conservation of Energy has a perfectly definite social implication"; economic stability could be achieved if society saved energy as they did dollars (ibid). As it was, energy went unaccounted for aside from its in terms of their monetary cost. What could be done? Scott's message was that the current ruling class of politicians, economists, and lawyers should be replaced by engineers and technicians who would manage the economy according to the principles of technological efficiency, in which the maximization of energy efficiency would be the goal rather than the pursuit of pecuniary wealth. Given the apparent failure of orthodox economics to solve the crisis, Scott's populist 'Technocracy Movement', the most prominent iteration of a more widely shared energetic productivism, enjoyed a brief period of populist credibility before orthodox economic thinking reasserted itself (Elsner 1967).

Scott's Technocracy movement has long been seen as an eccentric outlier in economic history, but we have presented two less well-known versions of energetic productivism that were central to state planning in Great Britain and the Soviet Union, and which both preceded this more well-known call for energy-driven development and exceeded it in consequence. Productivism with an accounting system based on labor, energetic prime movers, and resources, clearly contributed to more orthodox implementations of energomaterialist productivism at the beginning of the twentieth century, not least national electrification. Indeed, its advocates considered it more universal than later 'monetary' conceptions of the economy and a means to restore various perceived imbalances. With the League of Nations and the International Labor Organization poised to build an international statistical infrastructure, information on other countries was assembled from books, international conferences and economic journals and services. Energy constituted an energomaterial and quantifiable entity that could be measured across all economic sectors, on the basis of which states could compare and compete (Guyol 1960).

Energy productivists engaged in an indirect form of competition. We have shown that, in close observation, they strive to outdo their competitors, Germany in the British case, and the capitalist world in the Soviet case, in maximizing the productivity of land, labor and resources by utilizing electrical power. It is notable that there was very little debate about the overarching goal of energy productivism. Their goal was not a shared norm, an idea of what society should be, but a shared understanding of how economic progress could be achieved. In other words, energy productivism implies a theory of history as a teleological process of technological progress, a view accepted across the 
political spectrum. Because this goal was not absolute but one enacted via the efficacy of technologies that are always relative in efficiency, energetic productivism could entail endless competition. Moreover, as the interwar period shows, this competition was only 'formally' peaceful. For all its focus on domestic economic reform, energy policies remained linked to questions of national security, access to strategic resources, and capacity for armed conflict. Competition over the provision of power never ceased to have a double meaning.

\section{References}

Allen, Robert C. (2003): Farm to Factory. A Reinterpretation of the Soviet Industrial Debate, Princeton: Princeton University Press.

Arvay, Janos (1994): “The Material Product System. A Retrospective.” In: Zoltan Kennedy (ed.), The Accounts of Nations, Amsterdam: IOS Press, pp. 218236.

Bailes, Kendall E. (1977): "Alexei Gastev and the Soviet Controversy over Taylorism, 1918-24." In: Soviet Studies 29/3, pp. 373-394.

Bailes, Kendall E. (1978): Technology and Society under Lenin and Stalin: Origins of the Soviet Technical Intelligentsia, 1917-1941, Princeton: Princeton University Press.

Balzer, Harvey D. (1980): "Educating Engineers: Economic Politics and Technical Training in Tsarist Russia.” Ph.D., University of Pennsylvania.

Barnett, Vincent (2004): The Revolutionary Russian Economy, 1890-1940: Ideas, Debates and Alternatives, London: Routledge.

Breger, Herbert (1982): Die Natur als arbeitende Maschine: Zur Entstehung des Energiebegriffs in der Physik, 1840-1850, Frankfurt: Campus Verlag.

Cain, P. J. (2002): Hobson and Imperialism: Radicalism, New Liberalism, and Finance 1887-1938, Oxford: Oxford University Press.

Carr, Edward Hallett (1979): The Russian Revolution: from Lenin to Stalin, New York: Free Press.

Chandler, Alfred D. (2002): The Visible Hand: The Managerial Revolution in American Business, Cambridge, MA: Harvard University Press.

Cochrane, R. (1985): Power to the People: The Story of the National Grid, 19351985, Feltham: Newnes Books.

Coopersmith, Jonathan (1992): The Electrification of Russia, 1880-1926, Ithaca: Cornell University Press. 
Cummins, Alex G. (1988): "The Road to NEP, the State Commission for the Electrification of Russia (GOELRO): A Study in Technology, Mobilization, and Economic Planning." Ph.D., University of Michigan.

Davies, Robert William (1996): Crisis and Progress in the Soviet Economy, 19311933, London: Macmillan.

Elsner Jr., Henry (1967): Technocrats: Prophets of Automation, Syracuse: Syracuse University Press.

Erlich, Alexander (1967): The Soviet Industrialisation Debate, 1924-1928. Cambridge, MA: Harvard University Press.

Flakserman, Iuri N. (1964): Gleb Maksimilianovich Krzhizhanovskii, Moscow: Izdatel'stvo Nauka.

Friedberg, Aaron (1988): The Weary Titan: Britain and the Experience of Relative Decline, 1895-1905, Princeton: Princeton University Press.

Friedrich, Brestislav/James, Jeremiah (2017): "From Berlin-Dahlem to the Fronts of World War 1: The Role of Fritz Haber and His Kaiser Wilhelm Institute in German Chemical Warfare." In: Bretislav Friedrich, Dieter Hoffmann, Jürgen Renn, Florian Schmaltz, Martin Wolf (eds.), One Hundred Years of Chemical Warfare: Research, Deployment, Consequences, Cham: Springer, pp. 25-45.

Garavini, Giuliano (2019): The Rise \& Fall of OPEC in the Twentieth Century, Oxford: Oxford University Press.

Guyol, N. (1960): "Energy Consumption and Economic Development." In: Norton Ginsburg (ed.), Essays on Geography and Economic Development, Chicago: Chicago University Press.

Haldane, Richard B./Merz, Charles (1918): The Coal Conservation Committee, Final Report, London: HMSO.

Hannah, Leslie (1979): Electricity Before Nationalisation: A Study of the Development of the Electricity Supply Industry in Britain to 1948, London: Macmillan.

Hardach, Gerd (1981): The First World War, 1914-1918, Berkeley: University of California Press.

Haumann, Heiko (1974): Beginn der Planwirtschaft: Elektrifizierung, Wirtschaftsplanung und gesellschaftliche Entwicklung Sowjetrusslands, 19171921, Düsseldorf: Bertelsmann.

Hausman, William J./Hertner, Peter/Wilkins, Mira (2008): Global Electrification Multinational Enterprise and International Finance in the History of Light and Power, 1878-2007, Cambridge: Cambridge University Press. 
Hays, Samuel P. (1999): Conservation and the Gospel of Efficiency: The Progressive Conservation Movement, 1890-1920. Pittsburgh: University of Pittsburgh Press.

Hobsbawm, Eric J. (1989): The Age of Empire, 1875-1914, New York: Vintage. Hobson, John A. (1902): Imperialism: A Study, London: James Nisbet \& co. Hughes, Thomas P. (1993): Networks of Power: Electrification in Western Society, 1880-1930, Baltimore: JHU Press.

Jevons, Herbert (1931): 'The Second Industrial Revolution', In: The Economic Journal 41/161, pp. 1-18.

Karelin, E. G. (2010): “Zapadnaia Oblast Gosplana’: Iz Istorii Ekonomicheskogo Rayonirovaniya Strany v 1920-e Gody." In: Rossiiskaia Istoriia 2, pp. $15-18$.

Kearns, Gerry (2009): Geopolitics and Empire: The Legacy of Halford Mackinder. Oxford: Oxford University Press.

Krzhizhanovskii, Gleb M. (1924): "Elektrifikaciia i Planovoe Khoziaistvo [Electrification and the Planning Economy]." In: Planovoe Khoziaistvo 2, pp. 3-9.

Krzhizhanovskii, Gleb M. (1925a): "Perspektivy Elektrifikaciia [Perspectives of Electrification]." In: Planovoe Khoziaistvo 2, pp. 3-21.

Krzhizhanovskii, Gleb M. (1925b): "K peresmotru plana GOELRO [On a revision of the GOELRO plan].” In: Planovoe Khoziaistvo 7, pp. 7-28.

Krzhizhanovskii, Gleb M. (1928): "Zadachi Energeticheskogo Khosiaistva [Tasks of the Energy Economy].” In: Planovoe Khosiaistvo 6, pp. 7-43.

Krzhizhanovski, Gleb M. (1936 [1931]): "Osnovy techniko-ekonomicheskoi rekonstrukcii SSSR [The basis of the technical-economic reconstruction of the USSR]." In: Gleb M. Krzhizhanovskii (ed.), Sochineniia III: Socialisticheskoe Stroitel'stvo, Moscow: Gosudarstvennoe energeticheskoe izdatel'stvo, pp. 298-316.

Krzhizhanovskii, Gleb M. (1957): Voprosy ekonomicheskogo raionirovaniia SSSR. Sbornik materialov i statei (1917-1929 gg.) [Problems of Soviet economic regionalisation, a collection of materials and articles], Moscow: Gosudarstvennoe izdatel'stvo politicheskoi literatury.

Kukel', S. A. (1925): "Pervaia vsemirnaya konferenciia energetiki v Londone [First World Power Conference in London]." In: Planovoe Khoziaistvo 1, pp. 123-152.

Livingstone, David (2008): The Geographical Tradition: Episodes in the History of a Contested Enterprise, Oxford: Blackwell. 
Mackinder, Halford J. (1904): “The Geographical Pivot of History.” In: The Geographical Journal 23/4, pp. 421-437.

Mackinder, Halford J. (1905): "Man-Power as a Measure of National and Imperial Strength.” In: The National Review 44, pp. 136-143.

Mackinder, Halford J. (1906): Money-Power and Man-Power: the underlying principles rather than the statistics of tariff reform, London: Simpkin, Marshall \& Co. Ltd.

Maier, Charles (1970): "Between Taylorism and Technocracy: European Ideologies and the Vision of Industrial Productivity in the 1920s." In: Journal of Contemporary History 5, pp. 27-61.

Maier, Charles (1988): In Search of Stability: Explorations in Historical Political Economy, Cambridge: Cambridge University Press.

McKinnon, Andrew (2010): "Energy and society: Herbert Spencer's 'energetic sociology' of social evolution and beyond." In: Journal of Classical Sociology $10 / 4$, pp. $439-455$.

Meer, Elisabeth van (2012): "The Transatlantic Pursuit of a World Engineering Federation: For the Profession, the Nation, and International Peace, 1918-48." In: Technology and Culture 53/1, pp. 120-145.

Michalka, Wolfgang (1997): “From War Economy to 'New Economy': World War I and the Conservative Debate About the 'Other' Modernity in Germany." In: Bernd Hüppauf (ed.), War, Violence and the Modern Condition, Berlin: De Gruyter, pp. 77-95.

Mirowski, Philip (1989): More Heat than Light: Economics as Social Physics, Physics as Nature's Economics, Cambridge: Cambridge University Press.

Mirowski, Philip (2002): Machine Dreams: economics becomes a cyborg science, Cambridge: Cambridge University Press.

Mommsen, Wolfgang J. (1990): Max Weber and German Politics, 1890-1920, Chicago: University of Chicago Press.

Moser, Nat (2018): Oil and the Economy of Russia: From the Late-Tsarist to the Post-Soviet Period, London: Routledge, Taylor \& Francis Group.

Müller, Ernst (2020): "Energy.” In: Forum Interdisziplinäre Begriffsgeschichte 9/1, pp. 29-39.

Mumford, Lewis (1934): Technics and Civilization, Chicago: University of Chicago Press.

Nef, John (1932): The Rise of the British Coal Industry, London: George Routledge. 
Polelle, Mark (1999): Raising Cartographic Consciousness: The Social and Foreign Policy Vision of Geopolitics in the Twentieth Century, Lanham: Lexington Books.

Rabinbach, Anson (1992): The Human Motor: Energy, Fatigue, and the Origins of Modernity, Berkeley: University of California Press.

Rabinbach, Anson (2018): The Eclipse of the Utopias of Labor, New York: Fordham University Press.

Rose, Andreas (2017): Between Empire and Continent: British Foreign Policy before the First World War, New York: Berghahn Books.

Rubinstein, Modest (1971 [1931]): "Electrification as the Basis of Technical Reconstruction in the Soviet Union." Bukharin, N. et al, ed., Science at the Crossroads: Papers from the Second International Congress of the History of Science and Technology, 1931, London: Frank Cass \& Co, pp. 115-145.

Russ, Daniela (2021 forthcoming): "The Ennoblement of Nature: Gleb M. Krzhizhanovskii's 'Energetika' and Socialist Industrialization.” In: Historical Materialism.

Sampson, Anthony (1975): The Seven Sisters: The Great Oil Companies and the World They Made, London: Hodder and Stoughton.

Saul, S.B. (1985): The Myth of the Great Depression, 1873-1896, London: Macmillan.

Scally, Robert James (2015): The Origins of the Lloyd George Coalition: The Politics of Social Imperialism, 1900-1918, Princeton: Princeton University Press.

Schabas, Margaret (2005): The Natural Origins of Economics, Chicago: University of Chicago Press.

Scott, H. (1933): 'Technology Smashes the Price System." In: Harpers' Magazine 166, pp. 129-142.

Searle, Gerald (1971): The Quest for National Efficiency: A Study in British Political and Political Thought, 1899-1914, Berkeley: University of California Press.

Searle, Gerald (1976): Eugenics and Politics in Britain, 1900-1914, Leyden: Noordhoff.

Searle, Gerald (2002): “National Efficiency' and the 'Lessons' of the War." In: David Omissi/Andrew Thompson (eds.), The Impact of the South African War, London: Palgrave Macmillan, pp. 194-211.

Shearer, David R. (1996): Industry, State, and Society in Stalin's Russia, 19261934, Ithaca: Cornell University Press. 
Siegelbaum, Lewis H. (1992): Soviet State and Society between Revolutions, 1918-1929, Cambridge: Cambridge University Press.

Slobodian, Quinn (2018): Globalists. The End of Empire and the Birth of Neoliberalism, Cambridge, MA: Harvard University Press.

Smith, Neil (2003): American Empire: Roosevelt's Geographer and the Prelude to Globalization, Berkeley: University of California Press.

Snow, Alpheus Henry (1919): "The Mandatary System under the Covenant of the League of Nations." In: Proceedings of the Academy of Political Science in the City of New York 8/3, pp. 68-79.

Solvay, Ernest (1900): Notes sur le productivisme et le comptabilisme, Bruxelles: H. Lamertin.

State Planning Commission (1923): "Plenum Gosplana [Gosplan plenum]." In: Planovoe Khoziaistvo 6-7, pp. 39-76.

State Planning Commission (1930): Pervyi Piatiletnii Plan NarodnoKhoziaistvennogo Stroitel'stva SSSR [First Five Year Plan of the National Economic Construction of the USSR], Moscow: Izdatel'stvo Planovoe Khoziaistva.

Strachey, John (1959): The End of Empire. London: Gollancz.

Thomas, William (2015): Rational Action: The Sciences of Policy in Britain and America, 1940-1969, Cambridge, MA: MIT Press.

Thompson, Andrew S. (1997): "Tariff Reform: An Imperial Strategy, 1903-1913." In: The Historical Journal 40/4, pp. 1033-1054.

Tooze, Adam (2001): Statistics and the German State, 1900-1945: The Making of Modern Economic Knowledge, Cambridge: Cambridge University Press.

Tooze, Adam (2015): The Deluge: The Great War, America and the Remaking of Global Order, 1916-1931, London: Penguin.

Turnbull, Thomas (2020): 'Toward histories of saving energy: Erich Walter Zimmermann and the struggle against "one-sided materialistic determinism." In: Journal of Energy History/Revue d'Histoire de l'Énergie 1/4, unpaginated.

Tyrell, Ian (2015): Crisis of the Wasteful Nation: Empire in Theodore Roosevelt's America, Chicago: University of Chicago Press.

Underwood, Ted (1995): "Productivism and the Vogue for 'Energy' in Late Eighteenth-Century Britain.” In: Studies in Romanticism 34/1, pp. 103-125. Veblen, Thorstein (1975 [1921]): The Engineers and the Price System, New York: Augustus M. Kelly.

Wilkins, Mira (2009): The History of Foreign Investment in the United States, 1914-1945, Cambridge, MA: Harvard University Press. 
Wise, M. Norton/Smith, Crosbie (1989a): "Work and Waste: Political Economy and Natural Philosophy in Nineteenth Century Britain (I)." In: History of Science 27/3, pp. 263-301.

Wise, M. Norton/Smith, Crosbie (1989b): "Work and Waste: Political Economy and Natural Philosophy in Nineteenth Century Britain (II)." In: History of Science 27/4, pp. 391-449.

Wise, M. Norton/Smith, Crosbie (1990): "Work and Waste: Political Economy and Natural Philosophy in Nineteenth Century Britain (III)." In: History of Science 28/3, pp. 221-261.

World Power Conference (1925): The Transactions of the First World Power Conference, London, June 30th to July 12th, 1924, London: P. Lund, Humphries \& Co., Ltd.

Zimmermann, Erich (1933): World Resources and Industries: A Functional Appraisal of the Availability of Agricultural and Industrial Resources, New York: Harper \& Brothers. 